\title{
Promicromonospora enterophila sp. nov., a New Species of Monospore Actinomycetes
}

\author{
K. JÁGER, ${ }^{1}$ K. MÁRIALIGETI,${ }^{1 *}$ M. HAUCK,${ }^{2}$ AND G. BARABÁ $S^{3}$ \\ Department of Microbiology, Eötvös L. University, Budapest, Hungary, ${ }^{1}$ Institute of Biochemistry ${ }^{2}$ and \\ Biological Institute, ${ }^{3}$ University Medical School, Debrecen, Hungary
}

\begin{abstract}
Promicromonospora enterophila sp. nov., which was isolated from millipede feces, is the first species of the genus Promicromonospora for which the natural habitat is known. A comparison of this species with Promicromonospora citrea is presented. The type strain of $P$. enterophila is HMGB B1078 (= strain DFA-19).
\end{abstract}

Promicromonospora citrea, until now the only species in the genus Promicromonospora, was described by Krassilnikov et al. more than 20 years ago (12). At present we know of only three Promicromonospora strains besides the two randomly isolated but otherwise completely identical strains which were used for the original description of the genus Promicromonospora and the species $P$. citrea $(12,16)$. In Bergey's Manual of Determinative Bacteriology, 8th ed. (19), Luedeman placed Promicromonospora among the genera incertae sedis. However, 5 years later this genus was listed by Skerman et al. (22) on the Approved List of Bacterial Names. Recently, Lechevalier and Lechevalier $(14,15)$ have discussed the possible systematic relationship of this genus with very similar actinomycetes having cell wall type VI, such as Oerskovia and the nonmotile Oerskovia-like organisms (NMOs). All five strains of Promicromonospora investigated by these authors were gram-positive, oxidative organisms that produced branching substrate hyphae which broke into nonmotile fragments and sparse sterile aerial mycelia. According to Lechevalier and Lechevalier $(14,16)$, members of the genus Oerskovia and NMOs are similar in their abilities to ferment glucose, to grow anaerobically on Trypticase soy agar, and to utilize nitrates as terminal electron acceptors. In contrast to NMOs, cells of Oerskovia are motile, and their cell walls also contain galactose (cell wall type VI plus galactose).

Promicromonospora, Oerskovia, and NMOs have not been accepted in any of the known families of actinomycetes (14), and in our opinion, more detailed knowledge of the biochemistry and ecology of these organisms, as well as detailed investigations of more strains, will be required to place them in an existing family. Until recently, we knew nothing of the true natural habitats of these actinomycetes (17).
Without exception, the few strains which are available in international collections represent only random soil and laboratory isolates. We have detected the common occurrence of Promicromonospora-like actinomycetes in fresh fecal material of millipedes (Diplopoda) (4); thus, it is now possible to study these organisms much more intensively. In the present paper we describe the first new Promicromonospora species for which the natural habitat has been identified.

\section{MATERIALS AND METHODS}

Methods of isolation. Serial dilutions of aseptically collected fresh samples of excrement from Chromatoiulus projectus Verh. (Diplopoda; collected in August 1977 from the litter layer of a brown forest soil in western Hungary) were plated onto the following media: nutrient agar (medium B1; Difco Laboratories, Detroit, Mich.); synthetic glucose agar (20); starchcasein agar $(10.0 \mathrm{~g}$ of soluble starch, $1.0 \mathrm{~g}$ of casein, $0.5 \mathrm{~g}$ of $\mathrm{Na}_{2} \mathrm{HPO}_{4}, 15.0 \mathrm{~g}$ of agar, 1.0 liter of distilled water, $\mathrm{pH} 7.0$ to 7.2); and glycerol-arginine agar (5). After incubation for $72 \mathrm{~h}$ to 2 weeks at $28^{\circ} \mathrm{C}$, isolations were made randomly.

Investigated strains. Isolates were purified by repeated streaking and reisolation, numbered as strains, and maintained by continuous cultivation. A total of 54 freshly isolated strains were characterized, together with $P$. citrea type strain USSR RIA-562 (= ATCC 15908).

Maintenance and test conditions. Stock cultures were maintained on oatmeal agar (ISP medium 3) slopes at 4 to $6^{\circ} \mathrm{C}$. Subcultures were made at 4 -week intervals. Inoculated slants were incubated at $28^{\circ} \mathrm{C}$ for 1 week. One loopful of a 24-h-old nutrient agar slant culture or 1 drop (approximately $0.05 \mathrm{ml}$ ) of one loopful of surface growth suspended in $5 \mathrm{ml}$ of sterile physiological saline was used as the standard inoculum. Tests were carried out in duplicate, and cultures were incubated at $28^{\circ} \mathrm{C}$, except where indicated otherwise. Tests were read on day 7 of incubation, except where indicated otherwise.

Morphological and cultural characteristics. Morphological observations were made with an optical microscope. The preparations examined were plate cultures 


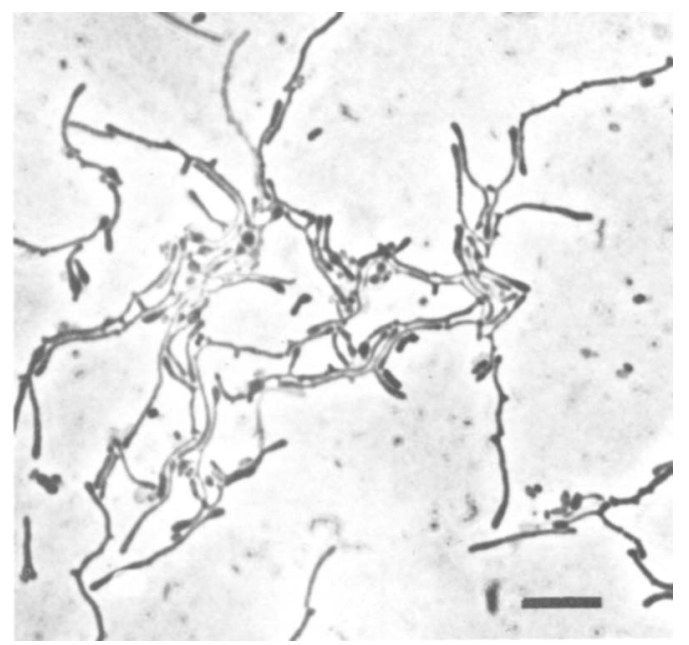

FIG. 1. Elongated, rarely branching substrate hyphae of $P$. enterophila strain DFA-17 on a starchcasein agar film in a moist-chamber culture after $24 \mathrm{~h}$ of incubation at $28^{\circ} \mathrm{C}$. Phase-contrast illumination. Bar $=10 \mu \mathrm{m}$.

and moist-chamber agar film cultures which had been grown on nutrient agar, yeast extract-starch agar (18), oatmeal agar, starch-casein agar, synthetic glucose agar, and potato agar $(200 \mathrm{~g}$ of peeled potatoes was minced and boiled in $500 \mathrm{ml}$ of tap water until the potatoes disintegrated; then the preparation was gauze filtered and made up to 1.0 liter with distilled water; the $\mathrm{pH}$ was adjusted to 6.5 , and the medium was autoclaved at $121^{\circ} \mathrm{C}$ for $20 \mathrm{~min}$ ). Pigment production was also examined on potato agar slants (18). Cultural characteristics were scored on the same media. Hucker Gram stains (8) and acid-fast stains (6) were used on 24- and 48-h-old cultures grown on nutrient agar and yeast extract-starch agar. Motility was tested by using wet-mount preparations that were examined by phase-contrast microscopy. Sporulation was detected by phase-contrast microscopy of moist-chamber agar film cultures and by examining broth culture smears; in these cases only yeast extract-starch medium was used, and incubation lasted for 3 weeks to 4 months.

Physiological and biochemical characteristics. Media and chemicals obtained from Difco Laboratories, Oxoid Ltd. Oxoid (Basingstoke, England), and E. Merck AG (Darmstadt, West Germany) were used to determine physiological and biochemical characteristics. The temperature range for growth was determined on yeast extract-starch agar and nutrient agar by using a temperature gradient incubator set at 5, 10, 28, 32, 37, 42,45 , and $50^{\circ} \mathrm{C}$. The ability to grow at $\mathrm{pH}$ values of 2 , $3,5,7,9$, and 11 was tested in yeast extract-starch broth $(10.0 \mathrm{~g}$ of yeast extract, $20.0 \mathrm{~g}$ of soluble starch, 1.0 liter of distilled water; the $\mathrm{pH}$ was adjusted with sterile $1.0 \mathrm{~N} \mathrm{HCl}$ or $1.0 \mathrm{~N} \mathrm{NaOH}$ after autoclaving). Resistance to osmotic pressure was determined on yeast extract-starch agar supplemented with 5, 7, 9, and $12 \%(\mathrm{wt} / \mathrm{vol}) \mathrm{NaCl}$. Oxidative or fermentative utilization of glucose and cellulose (MN 300 Cellulose- pulver für Dünnschichtchromatographie; MachereyNagel et Co., Düren, West Germany) was tested by the method of Hugh and Leifson (9). Glucose was added as a Seitz EK-filtered solution, and cellulose was autoclaved in the medium at $121^{\circ} \mathrm{C}$ for $10 \mathrm{~min}$. Oxidation and fermentation of glucose were also checked in a tris(hydroxymethyl)aminomethane-buffered medium $[1.0 \mathrm{~g}$ of Casitone, $0.1 \mathrm{~g}$ of yeast extract $0.5 \mathrm{~g}$ of $\left(\mathrm{NH}_{4}\right)_{2} \mathrm{SO}_{4}, 0.5 \mathrm{~g}$ of tris(hydroxymethyl)aminomethane(sodium salt), $3.0 \mathrm{~g}$ of agar, $0.01 \mathrm{~g}$ of phenol red, 1.0 liter of distilled water; the $\mathrm{pH}$ was adjusted to 7.5 with approximately $0.3 \mathrm{ml}$ of $1.0 \mathrm{~N} \mathrm{HCl}$ per $100 \mathrm{ml}$ of medium; a Seitz EK-filtered glucose solution was added to a final concentration of $1 \%(\mathrm{wt} / \mathrm{vol})]$. A test was considered positive if the $\mathrm{pH}$ value decreased $1 \mathrm{U}$ (i.e., the medium turned yellow) during 1 week of incubation. Cellulase production also was determined in a cellulose strip yeast extract broth (18). The ability to grow anaerobically (Anaerobic System; Oxoid) was determined on tryptic soy agar (Difco) and nutrient agar.

Catalase production was determined on 5-day-old cultures on yeast extract-starch agar and nutrient agar dropped with $3 \%$ hydrogen peroxide. Phosphatase activity was scored by the method of Cowan and Steel (3). The Christensen urease test was used to detect urea decomposition. Deamination of phenylalanine was determined by the method of Gordon (7). Casein hydrolysis, gelatin hydrolysis, starch hydrolysis, tributyrin hydrolysis, tryosine hydrolysis, xanthine hydrolysis, and hypoxanthine hydrolysis were examined by incorporating $1 \%$ skim milk, $0.5 \%$ gelatin, $0.4 \%$ soluble starch, $0.2 \%$ tributyrin, $0.5 \%$ tyrosine, $0.4 \%$ xanthine, and $0.5 \%$ hypoxanthine, respectively, into nutrient agar. Liquefaction of gelatin also was detected by the method of Kohn (11) on nutrient agar slants. Ribonuclease and deoxyribonuclease activities were

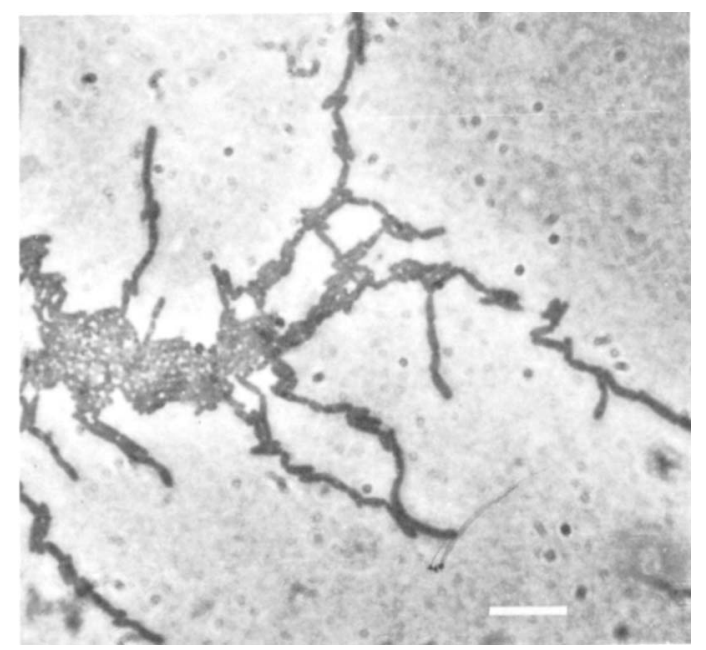

FIG. 2. Disintegrating microcolony of $P$. enterophila strain DFA-17 on a nutrient agar film in a moistchamber culture after $72 \mathrm{~h}$ of incubation at $28^{\circ} \mathrm{C}$. The elongated hyphal filaments are fragmenting into coccoid and bacillary elements. Phase-contrast illumination. Bar $=10 \mu \mathrm{m}$. 


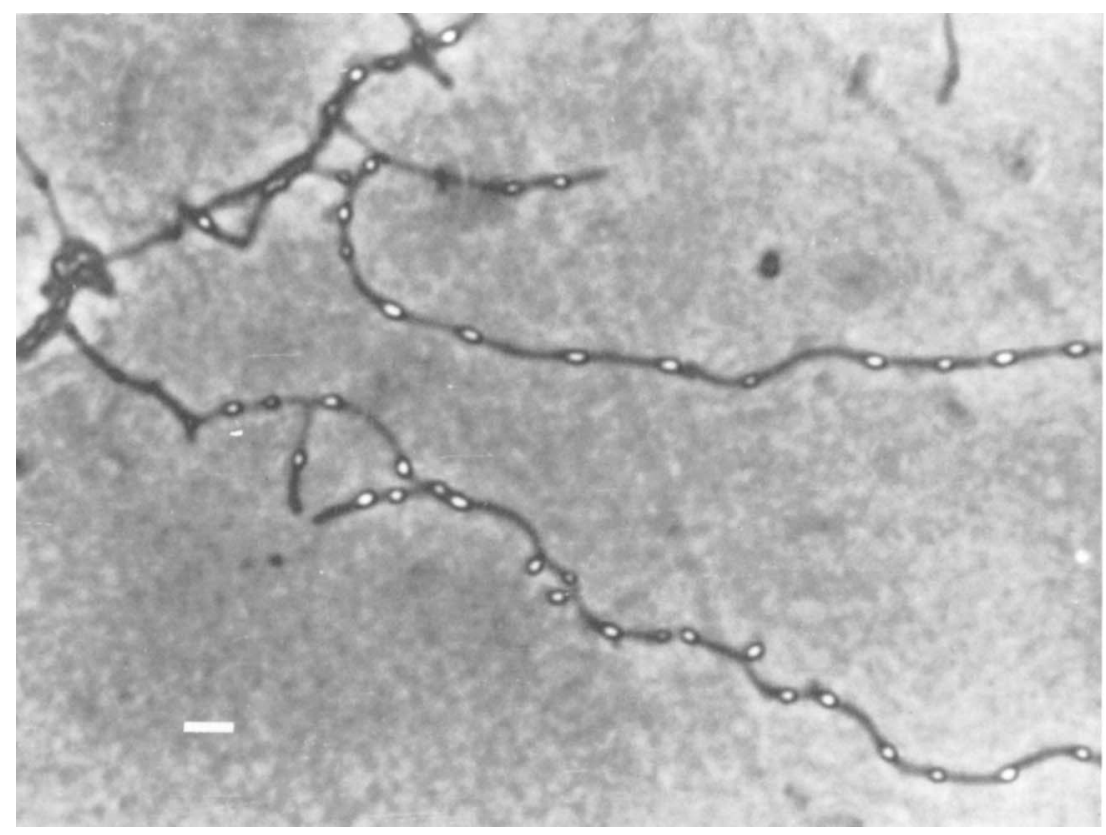

FIG. 3. Sessile oval spores located singly on the relatively rarely branching substrate hyphal filaments in a moist-chamber culture of $P$. enterophila DFA-51 after 34 days of incubation on a starch-casein agar film at $28^{\circ} \mathrm{C}$. Phase-contrast illumination. Bar $=10 \mu \mathrm{m}$.

determined by the method of Jeffries et al. (10).

Production of melanoid pigments and utilization of carbohydrates were tested by the methods of the International Streptomyces Project (21). To examine decomposition of organic acids, a modified Koser medium $\left[1.0 \mathrm{~g}\right.$ of $\mathrm{NaCl}, 0.2 \mathrm{~g}$ of $\mathrm{MgSO}_{4} \cdot 7 \mathrm{H}_{2} \mathrm{O}, 1.0 \mathrm{~g}$ of $\left(\mathrm{NH}_{4}\right)_{2} \mathrm{HPO}_{4}, 0.5 \mathrm{~g}$ of $\mathrm{KH}_{2} \mathrm{PO}_{4}, 15.0 \mathrm{~g}$ of agar, $0.01 \mathrm{~g}$ of phenol red, 1.0 liter of distilled water] was adjusted to $\mathrm{pH}$ 6.8, and Seitz EK filter-sterilized solutions of sodium salts of organic acids were added to the medium to final concentrations of $0.2 \%(\mathrm{wt} / \mathrm{vol})$. The other tests used have been described previously (20).

Cell wall analysis. Cells grown in shake cultures in yeast extract-starch broth for 3 days at $28^{\circ} \mathrm{C}$ were harvested by centrifugation and washed three times in sterile saline at $2^{\circ} \mathrm{C}$. Crude cell wall preparations were obtained by crushing cells in an X-press and centrifuging the resulting suspension to remove conidia and intact hyphal bits. The procedure of Barabás and Szabó (1) was used for further analyses.

\section{RESULTS AND DISCUSSION}

Among the actinomycete isolates which were obtained from fecal pellets collected aseptically under laboratory conditions within 2 to $3 \mathrm{~h}$ after defecation by the millipede $C$. projectus, about $87 \%$ were Promicromonospora-like organisms. We found that these isolates included only one species of the genus Promicromonospora. Of the 61 strains which were purified for further studies, 7 lost viability. The remaining 54 strains grew well and formed typical gram-positive, non-acid-fast, monopodially branched hyphae that were 0.5 to $1.0 \mu \mathrm{m}$ in diameter (Fig. 1). Hyphae growing on the surface or penetrating into the agar medium fragmented into bacillary or coccoid cells after 24 to $72 \mathrm{~h}$ of development (Fig. 2). On each test medium the hyphal structure was evident (Table 1). In smears growth appeared bacteroid; motility was never detected. Single sessile, oval spores (diameter, $1 \mu \mathrm{m}$ ) were observed on the hyphal filaments of the substrate mycelia of only six strains (11\%; Fig. $3)$. These spores did not tolerate heat treatment at $80^{\circ} \mathrm{C}$ for $5 \mathrm{~min}$.

Two colony types were produced by all strains; some colonies were pale yellow, glistening, soft, pasty, and "smooth" and appeared to be similar to the colonies of true bacteria. In this colony type the mycelium continuously fragmented into short elements, and definite hyphal structures could be observed only at the spreading edges of the colonies. The second colony type was a dull, "rough," wrinkled form which contained mostly hyphal components and could be removed from the agar medium as a strongly coherent unit of closely woven hyphae. Repeated single-colony isolations failed to separate the smooth and rough colony types. Both types of colonies of all strains produced a pale yellow endopigment, but we found no water-soluble pigments in the test media or melanoid pigments in ISP media 6 and 7. Aerial mycelium was never detected. 
TABLE 1. Comparison of the cultural characteristics of the type strains of $P$. enterophila sp. nov. and $P$. citrea $^{a}$

\begin{tabular}{|c|c|c|c|c|c|c|}
\hline \multirow[b]{2}{*}{ Medium } & \multicolumn{3}{|c|}{ P. enterophila DFA $-19^{\mathrm{T}}$} & \multicolumn{3}{|c|}{$P$. citrea ATCC $15908^{\mathrm{T}}$} \\
\hline & Growth & $\begin{array}{l}\text { Color of } \\
\text { colonies }\end{array}$ & $\begin{array}{c}\text { Aerial } \\
\text { mycelium }\end{array}$ & Growth & $\begin{array}{l}\text { Color of } \\
\text { colonies }\end{array}$ & Aerial mycelium \\
\hline Nutrient agar & $\begin{array}{l}\text { Good, smooth } \\
\text { colonies }\end{array}$ & $\begin{array}{c}1 \text { ba, pale } \\
\text { yellow }\end{array}$ & None & $\begin{array}{l}\text { Good, smooth } \\
\text { colonies }\end{array}$ & $\begin{array}{c}1 \frac{1}{2} \mathrm{fb}, \text { light } \\
\text { yellow }\end{array}$ & None \\
\hline $\begin{array}{l}\text { Yeast extract- } \\
\text { starch agar }\end{array}$ & $\begin{array}{l}\text { Poor, often rough } \\
\text { colonies }\end{array}$ & $\begin{array}{c}11 / 2 \mathrm{fb}, \text { light } \\
\text { yellow }\end{array}$ & None & $\begin{array}{l}\text { Good, often rough } \\
\text { colonies }\end{array}$ & $\begin{array}{c}1 \frac{1}{2} \mathrm{fb} \text {, light } \\
\text { yellow }\end{array}$ & None \\
\hline Oatmeal agar & $\begin{array}{l}\text { Moderate, smooth } \\
\text { colonies }\end{array}$ & $\begin{array}{c}1 \text { ba, pale } \\
\text { yellow }\end{array}$ & None & $\begin{array}{l}\text { Moderate, smooth } \\
\text { colonies }\end{array}$ & $\begin{array}{c}11 / 2 \mathrm{fb}, \text { light } \\
\text { yellow }\end{array}$ & Traces \\
\hline $\begin{array}{l}\text { Starch-casein } \\
\quad \text { agar }\end{array}$ & Poor & $\begin{array}{l}1 \text { ba, pale } \\
\text { yellow }\end{array}$ & None & $\begin{array}{l}\text { Good, smooth } \\
\text { colonies }\end{array}$ & $\begin{array}{l}1 \text { ba, pale } \\
\text { yellow }\end{array}$ & None \\
\hline $\begin{array}{l}\text { Synthetic } \\
\text { glucose } \\
\text { agar }\end{array}$ & $\begin{array}{l}\text { Moderate, smooth } \\
\text { colonies }\end{array}$ & $\begin{array}{l}2 \mathrm{fb}, \text { light } \\
\text { yellow }\end{array}$ & None & $\begin{array}{l}\text { Good, smooth } \\
\text { colonies }\end{array}$ & $\begin{array}{c}11 / 2 \mathrm{fb}, \text { light } \\
\text { yellow }\end{array}$ & None \\
\hline Potato agar & $\begin{array}{l}\text { Good, smooth } \\
\text { colonies }\end{array}$ & $\begin{array}{c}11 / 2 \mathrm{fb} \text {, light } \\
\text { yellow }\end{array}$ & None & Good & $\begin{array}{c}11 / 2 \mathrm{fb}, \text { light } \\
\text { yellow }\end{array}$ & $\begin{array}{l}\text { Colorless to } 13 \\
\text { ba, purplish } \\
\text { white }\end{array}$ \\
\hline
\end{tabular}

${ }^{a}$ The color codes and names are from the Tresner-Backus color wheels (23).

All of our strains were facultatively anaerobic, and growth on nutrient medium and tryptic soy medium under anaerobic conditions became intensive after $72 \mathrm{~h}$ of incubation at $28^{\circ} \mathrm{C}$. Glucose was attacked both oxidatively and fermentatively. Breakdown of cellulose was not detected. Good growth was observed on synthetic glucose medium supplemented with an inorganic $\mathrm{N}$ source. Nitrites were produced from nitrates.

All isolates were negative for indole, the Voges-Proskauer test, and oxidase and positive for methyl red, catalase, and deoxyribonuclease. Phenylalanine was not deaminated. Urease and phosphatase activities were variable. All isolates hydrolyzed tributyrin. Casein breakdown and starch breakdown were extremely slow. All strains failed to hydrolyze Tween 80 , esculin, ribonucleic acid, tyrosine, xanthine, and hypoxanthine, and $63 \%$ of the strains liquefied gelatin after 21 days. Without exception our isolates grew at $\mathrm{pH} 3.0$, in $5 \% \mathrm{NaCl}$, and at $32^{\circ} \mathrm{C}$.

On ISP medium 9 dextrin, fructose, galactose, glycerol, lactose, maltose, mannose, sucrose, salicin, soluble starch, trehalose, and xylose were utilized by most of the strains. Adonitol, dulcitol, inositol, inulin, mannitol, melibiose, melezitose, raffinose, rhamnose, sorbitol, and sorbose were not utilized. Our isolates produced acid from acetate and pyruvate, but not from benzoate, citrate, malate, oxalate, salycilate, or tartrate (Table 2). Table 3 shows the susceptibilities of the strains to antimicrobial compounds. Large differences were observed in susceptibility to penicillin.

Representative strain DFA-19 ${ }^{\mathrm{T}}$ (type strain) has a type VI cell wall chemical composition (13); the cell wall does not contain diaminopimelic acid isomers, but lysine, alanine, glutamine, and threonine are present at a molar ratio of $1: 1: 1.08: 0.3$. In our cell wall preparations aspartic acid, serine, proline, glycine, cysteine, methionine, leucine, isoleucine, phenylalanine, tyrosine, histidıne, and arginine were absent. Rhamnose, mannose, fucose, and glucosamine were detected in the cell walls, but glucose, galactose, galactosamine, ribose, arabinose, and xylose were not detected.

Our data indicate that our fecal isolates belong to the group of actinomycetes comprising Oerskovia, Promicromonospora, and NMOs. In contrast to Oerskovia, the mycelia of Promicromonospora strains do not fragment into flagellated, moving elements, but Promicromonospora species develop spores located singly on the hyphal filaments. Spore production by Promicromonospora strains is uncommon; for example, Lechevalier (16) never found spores in the cultures of her Promicromonospora isolates. The overwhelming majority of our strains also failed to produce spores. We observed sporulation in only six isolates after 6 to 8 weeks of incubation.

According to Lechevalier and Lechevalier (15), the presence of galactose in the cell wall (cell wall type VI plus galactose) is also an important distinguishing feature of oerskoviae. This carbohydrate is lacking in the cell walls of NMOs and Promicromonospora. However, Yamaguchi (24) found a considerable amount of galactose in the cell wall of the type strain of $P$. citrea (strain USSR RIA-562). Wall preparations of our representative strain DFA- $19^{\mathrm{T}}$ did not contain galactose, and in this respect this strain is similar to the strains of Promicromonospora described by Lechevalier and Lechevalier. On the other hand, strains of Oerskovia differ from $P$. citrea by their ability to ferment glucose (14, 
TABLE 2. Comparison of 54 strains of $P$. enterophila sp. nov. with $P$. enterophila strain DFA-19 $9^{\mathrm{T}}$ and $P$. citrea strain ATCC $15908^{\mathrm{T}}$

\begin{tabular}{|c|c|c|c|c|c|c|c|}
\hline \multirow[b]{2}{*}{ Property or test } & \multicolumn{2}{|c|}{ P. enterophila } & \multirow{2}{*}{$\begin{array}{c}P . \text { citrea } \\
\text { ATCC } \\
15908^{\mathrm{T}}\end{array}$} & \multirow[b]{2}{*}{ Property or test } & \multicolumn{2}{|c|}{$P$. enterophila } & \multirow{2}{*}{$\begin{array}{c}P \text {. citrea } \\
\text { ATCC } \\
15908^{\mathrm{T}}\end{array}$} \\
\hline & $\begin{array}{c}54 \\
\text { Strains }\end{array}$ & $\begin{array}{c}\text { Strain } \\
\text { DFA-19 }\end{array}$ & & & $\begin{array}{c}54 \\
\text { Strains }\end{array}$ & $\begin{array}{c}\text { Strain } \\
\text { DFA-19 }\end{array}$ & \\
\hline Gram stain reaction & $+(100)^{a}$ & + & + & Growth at: & & & \\
\hline Spores & $-(89)$ & - & + & $5^{\circ} \mathrm{C}$ & $+(100)$ & + & - \\
\hline Motility & $-(100)$ & - & - & $10^{\circ} \mathrm{C}$ & $+(100)$ & + & + \\
\hline Glucose breakdown & & & & $32^{\circ} \mathrm{C}$ & $+(90)$ & + & + \\
\hline (Hugh-Leifson) & & & & $37^{\circ} \mathrm{C}$ & $\mathrm{V}$ & - & + \\
\hline Oxidative & $+(96)$ & + & + & $42^{\circ} \mathrm{C}$ & $-(100)$ & - & + \\
\hline Fermentative & $+(98)$ & + & + & $45^{\circ} \mathrm{C}$ & $-(100)$ & - & - \\
\hline Glucose breakdown & & & & $\mathrm{pH}$ tolerance & & & \\
\hline (Tris-buffered & & & & 2 & $-(100)$ & - & - \\
\hline medium $)^{b}$ & & & & 3 & $+(100)$ & + & - \\
\hline Oxidative & $+(93)$ & + & \pm & 5 & $+(87)$ & + & + \\
\hline Fermentative & $+(96)$ & + & \pm & 9 & $+(100)$ & + & + \\
\hline Cellulose breakdown & & & & 11 & $+(100)$ & + & + \\
\hline $\begin{array}{l}\text { (Hugh-Leifson) } \\
\text { Oxidative }\end{array}$ & $-(100)$ & & & $\mathrm{NaCl}$ tolerance & $+(100)$ & & \\
\hline $\begin{array}{l}\text { Oxidative } \\
\text { Fermentative }\end{array}$ & $\begin{array}{l}-(100) \\
-(100)\end{array}$ & $\begin{array}{l}- \\
-\end{array}$ & $\begin{array}{l}- \\
-\end{array}$ & $\begin{array}{l}5 \% \\
7 \%\end{array}$ & $\begin{array}{l}+(100) \\
-(79)\end{array}$ & & + \\
\hline Cellulose strip & $-(100)$ & - & - & $9 \%$ & $-(100)$ & $\begin{array}{l}+ \\
-\end{array}$ & $\begin{array}{l}+ \\
+\end{array}$ \\
\hline Anaerobic growth & & & & $12 \%$ & $-(100)$ & - & $\begin{array}{l}+ \\
-\end{array}$ \\
\hline Tryptic soy agar & $+(96)$ & + & - & Utilization of: & & & \\
\hline Nutrient agar & $+(96)$ & + & - & Adonitol & $-(100)$ & - & - \\
\hline Growth on synthetic & $+(100)$ & + & + & Arabinose & $\mathrm{V}$ & + & + \\
\hline glucose agar & & & & Dextrin & $+(83)$ & + & + \\
\hline Nitrite from nitrates & $+(96)$ & + & - & Dulcitol & $-(77)$ & - & - \\
\hline Indole & $-(100)$ & - & - & Fructose & $+(94)$ & + & + \\
\hline Methyl red & $+(100)$ & + & - & Galactose & $+(78)$ & + & + \\
\hline Voges-Proskauer & $-(100)$ & - & - & Glycerol & $+(88)$ & + & + \\
\hline Catalase & $+(100)$ & + & + & Inositol & $-(98)$ & - & - \\
\hline Oxidase & $-(100)$ & - & - & Inulin & $-(90)$ & - & - \\
\hline Phenylalanine & $-(100)$ & - & - & Lactose & $+(88)$ & + & + \\
\hline deamination & & & & Maltose & $+(90)$ & + & + \\
\hline Urease & $\mathrm{V}^{\mathrm{c}}$ & + & - & Mannitol & $-(100)$ & - & + \\
\hline Phosphatase & V & \pm & + & Mannose & $+(90)$ & + & + \\
\hline Hydrolysis of: & & & & Melibiose & $-(60)$ & + & + \\
\hline Casein ${ }^{d}$ & \pm & \pm & + & Melezitose & $-(63)$ & + & + \\
\hline $\mathrm{Starch}^{d}$ & $\pm(90)$ & + & + & Raffinose & $-(94)$ & - & + \\
\hline Tween 80 & $-(98)$ & - & + & Rhamnose & $-(81)$ & - & + \\
\hline Tributyrin & $+(100)$ & + & + & Sucrose & $+(96)$ & + & + \\
\hline Esculin & $-(77)$ & - & + & Salicin & $+(69)$ & - & + \\
\hline Deoxyribonucleic acid & $+(100)$ & + & + & Soluble starch & $+(96)$ & + & + \\
\hline Ribonucleic acid & $-(96)$ & - & + & Sorbitol & $-(89)$ & - & - \\
\hline Tyrosine & $-(100)$ & - & + & Sorbose & $-(85)$ & - & - \\
\hline Xanthine & $-(100)$ & - & - & Trehalose & $+(79)$ & + & + \\
\hline Hypoxanthine & $-(98)$ & - & - & Xylose & $+(90)$ & + & + \\
\hline Gelatin & $-(98)$ & - & + & Acetate & $+(100)$ & + & + \\
\hline Gelatin liquefaction $(21$ & $+(63)$ & + & + & Benzoate & $-(100)$ & - & - \\
\hline days) & & & & Citrate & $-(100)$ & - & + \\
\hline Melanoid pigment & & & & Malate & $-(100)$ & - & + \\
\hline ISP medium 6 & $-(100)$ & - & - & Oxalate & $-(100)$ & - & - \\
\hline ISP medium 7 & $-(100)$ & - & - & Pyruvate & $+(100)$ & + & + \\
\hline & & & & Salicylate & $-(100)$ & - & - \\
\hline & & & & Tartrate & $-(100)$ & - & - \\
\hline
\end{tabular}

${ }^{a}$ The numbers in parentheses indicate the percentages of positive or negative strains.

${ }^{b}$ Tris, Tris(hydroxymethyl)aminomethane.

c V, Variable.

${ }^{d}$ Hydrolysis of casein and hydrolysis of starch were extremely slow. 
TABLE 3. Comparison of the susceptibilities of 54 strains of $P$. enterophila sp. nov. with the susceptibilities of $P$. enterophila DFA $-19^{\mathrm{T}}$ and $P$. citrea ATCC $15908^{\mathrm{T}}$

\begin{tabular}{|c|c|c|c|}
\hline \multirow[b]{2}{*}{ Antimicrobial compound } & \multicolumn{2}{|c|}{$P$. enterophila } & \multirow{2}{*}{$\begin{array}{c}P \text {. citrea } \\
\text { ATCC } \\
15908^{\mathrm{T}}\end{array}$} \\
\hline & $\begin{array}{c}54 \\
\text { Strains }\end{array}$ & DFA $-19^{\mathrm{T}}$ & \\
\hline Ampicillin $(20 \mu \mathrm{g})^{a}$ & $\mathrm{~S}(98)^{b}$ & S & $S$ \\
\hline Carbenicillin $(50 \mu \mathrm{g})$ & $\mathrm{S}(98)$ & S & $\mathrm{S}$ \\
\hline Cephalosporine $(10 \mu \mathrm{g})$ & $S(100)$ & S & S \\
\hline Chloramphenicol $(30 \mu \mathrm{g})$ & $S(98)$ & $\mathrm{S}$ & $S$ \\
\hline Chlortetracycline $(30 \mu \mathrm{g})$ & $\mathrm{S}(71)$ & $\mathrm{S}$ & $S$ \\
\hline Erythromycin $(10 \mu \mathrm{g})$ & $\mathrm{S}(98)$ & $\mathrm{S}$ & S \\
\hline Gentamicin $(20 \mu \mathrm{g})$ & $\mathrm{S}(98)$ & $\mathrm{S}$ & $S$ \\
\hline Methycillin $(20 \mu \mathrm{g})$ & $\mathrm{R}(98)$ & $\mathrm{R}$ & $\mathbf{R}$ \\
\hline Nalidixic acid $(30 \mu \mathrm{g})$ & $\mathrm{R}(100)$ & $\mathrm{R}$ & $\mathrm{R}$ \\
\hline Neomycin $(100 \mu \mathrm{g})$ & $\mathrm{S}(96)$ & $\mathrm{S}$ & $S$ \\
\hline Nitrofurantoin $(300 \mu \mathrm{g})$ & $\mathrm{R}(100)$ & $\mathrm{R}$ & $\mathbf{R}$ \\
\hline Nystatin (100 IU) & $\mathrm{R}(100)$ & $\mathrm{R}$ & $\mathbf{R}$ \\
\hline Oleandomycin $(30 \mu \mathrm{g})$ & $\mathrm{S}(92)$ & $\mathrm{S}$ & $\mathrm{S}$ \\
\hline Oxacillin $(10 \mu \mathrm{g})$ & $\mathrm{R}(87)$ & $\mathrm{R}$ & $\pm^{c}$ \\
\hline Paromomycin $(50 \mu \mathrm{g})$ & $\mathrm{S}(98)$ & $\mathrm{S}$ & $\mathrm{S}$ \\
\hline Penicillin (3 IU) & $\mathrm{V}^{d}$ & $\mathrm{R}$ & $\mathrm{S}$ \\
\hline Pristinamycin $(10 \mu \mathrm{g})$ & $S(100)$ & $\mathrm{S}$ & $\mathbf{S}$ \\
\hline Spiramycin $(30 \mu \mathrm{g})$ & $S(100)$ & $\mathrm{S}$ & $\mathrm{S}$ \\
\hline Sumetrolim $(25 \mu \mathrm{g})$ & $\mathrm{R}(98)$ & $\mathrm{R}$ & $\mathrm{R}$ \\
\hline Superseptyl $(400 \mu \mathrm{g})$ & $\mathrm{R}(98)$ & $\mathrm{R}$ & $\mathrm{R}$ \\
\hline Streptomycin $(30 \mu \mathrm{g})$ & $S(98)$ & $\mathrm{S}$ & $\mathrm{S}$ \\
\hline Vancomycin $(50 \mu \mathrm{g})$ & $S(100)$ & $\mathrm{S}$ & $S$ \\
\hline
\end{tabular}

${ }^{a}$ The numbers in parentheses indicate the disk concentrations.

${ }^{b}$ The numbers in parentheses indicate the percentages of susceptible $(\mathrm{S})$ and resistant $(\mathrm{R})$ strains.

c Susceptibility was detected, but light growth appeared in the zone of inhibition.

${ }^{d} \mathrm{~V}$, Variable.

16); in this respect, Oerskovia strains resemble NMOs. However, we found that the type strain of $P$. citrea attacks glucose weakly both oxidatively and fermentatively but that acid production is insufficient to decrease the $\mathrm{pH}$ value below 6.8 in tris(hydroxymethyl)aminomethanebuffered agar.

Based on the results of a comparative investigation of our monospore fecal actinomycete strains and the type strain of $P$. citrea and previous descriptions of Oerskovia spp. and NMOs, we conclude that our strains are most closely related to $P$. citrea. However, our fecal strains differ significantly from $P$. citrea in a number of characteristics, as shown in Tables 1 and 2 . These differences indicate that the monospore actinomycetes isolated from the hind gut and feces of the millipede $C$. projectus are distinct from the $P$. citrea strains which were isolated and described in 1961 by Krassilnikov et al. (12). Consequently, we consider our strains to be members of a new species of Promicromonospora, the description of which we present below.
Promicromonospora enterophila sp. nov. (en. ter. o' phi. la.) Gr. neu. pl. noun entera innards, guts; Gr. adj. philos loving; N.L. fem. adj. enterophila gut loving. The well-developed, monopodially branching, gram-positive, nonacid-fast vegetative hyphae (diameter, 0.5 to 1.0 $\mu \mathrm{m})$ fragment into nonmotile bacillary and coccoid elements. No aerial mycelium. Oval, sessile spores occur singly on the substrate hyphae. In smears growth appears bacteroid. In general, colonies are glistening, soft, pasty, and pale yellow in color. On starch-yeast extract media rough, wrinkled, dull colony variants also are observed. Water-soluble diffusible pigments and melanins are not produced.

The cultural and biochemical characteristics of the species are shown in Tables 1 and 2. The susceptibilities to antimicrobial compounds are shown in Table 3.

The cell wall is type VI, and the cell wall amino acids include lysine, alanine, glutamine, and threonine; the cell wall sugars are rhamnose, mannose, fucose, and glucosamine.

Isolated from fresh fecal pellets of $C$. projectus Verh. (Diplopoda, Myriapoda).

The type strain is strain DFA-19 (= HMGB B 1078). Strain DFA-17 (= HMGB B 1077) has also been deposited as a reference strain in the Hungarian Microbiology Gene Bank (HMGB), Budapest, Hungary.

\section{LITERATURE CITED}

1. Barabás, G., and G. Szabó. 1965. A comparison of cellwall composition of Streptomyces griseus strains. Arch. Microbiol. 50:156-163.

2. Christensen, W. B. 1946. Urea decomposition as a means of differentiating Proteus and paracolon cultures from each other and from Salmonella and Shigella. J. Bacteriol. 52:461-466.

3. Cowan, S. T., and K. J. Steel. 1965. Manual for the identification of medical bacteria. University Press, Cambridge.

4. Dzingov, A., K. Márialigeti, K. Jáger, E. Contreras, L. Kondics, and I. M. Szabó. 1982. Studies on the microflora of millipedes (Diplopoda). I. A comparison of actinomycetes isolated from surface structures of the exoskeleton and the digestive tract. Pedobiologia 24:1-7.

5. El-Nakeeb, M. A., and H. A. Lechevalier. 1963. Selective isolation of aerobic actinomycetes. Appl. Microbiol. 11:75-77.

6. Gordon, R. E. 1966. The taxonomy of soil bacteria, p. 293-321. In T. R. G. Gray and B. Parkinson (ed.), The ecology of soil bacteria. Liverpool University Press, Liverpool.

7. Gordon, R. E., and M. M. Smith. 1955. Proposed group of characters for the separation of Streptomyces and Nocardia. J. Bacteriol. 69:147-150.

8. Hucker, G. J., and H. J. Conn. 1983. Methods of Gram staining. N.Y. State Agric. Exp. Stn. Geneva Technol. Bull. 93:1-34.

9. Hugh, R., and E. Leifson. 1953. The taxonomic significance of fermentative versus oxidative metabolism of carbohydrates by various gram-negative bacteria. J. Bacteriol. 66:24-26

10. Jeffries, C. D., D. F. Holtman, and D. G. Guze. 1957. Rapid method for determining the activity of microorganisms on nucleic acids. J. Bacteriol. 73:590-591. 
11. Kohn, J. 1953. The use of denaturated gelatin for biochemical tests. J. Clin. Pathol. 6:250.

12. Krassilnikov, N. A., L. V. Kalakoutskii, and N. F. Kirillova. 1961. A new genus of Actinomycetales, Promicromonospora gen. nov. Izv. Akad. Nauk SSSR Ser. Biol., p. 107-112. (In Russian.)

13. Lechevalier, H. A., and M. P. Lechevalier. 1970. A critical evaluation of the genera of aerobic actinomycetes, p. 393405. In $\mathrm{H}$. Prauser (ed.), The Actinomycetales. Gustav Fischer, Jena.

14. Lechevalier, H. A., and M. P. Lechevalier. 1981. Actinomycete genera "in search of a family," p. 2118-2123. In M. P. Starr, H. Stolp, H. G. Trüper, A. Balows, and H. G. Schlegel (ed.), The procaryotes. A handbook on habitats, isolation, and identification of bacteria. Springer-Verlag, Berlin.

15. Lechevalier, H. A., and M. P. Lechevalier. 1981. Introduction to the order Actinomycetales, p. 1915-1922. In M. P. Starr, H. Stolp, H. G. Trüper, A. Balows, and H. G. Schlegel (ed.), The procaryotes. A handbook on habitats, isolation, and identification of bacteria. Springer-Verlag, Berlin.

16. Lechevalier, M. P. 1972. Description of a new species, Oerskovia xanthineolytica, and emendation of Oerskovia Prauser et al. Int. J. Syst. Bacteriol. 22:260-264.
17. Lechevalier, M. P. 1981. Ecological associations involving actinomycetes. Zentralbl. Bakteriol. Microbiol. Hyg. Abt. 1 Suppl. 11:159-166.

18. Leudeman, G. M. 1971. Micromonospora purpureochromogenes (Waksman and Curtis 1916) comb. nov. Int. J. Syst. Bacteriol. 21:240-247.

19. Luedeman, G. M. 1974. Addendum to Micromonosporaceae, p. 863-865. In R. E. Buchanan and N. E. Gibbons (ed.), Bergey's manual of determinative bacteriology, 8th ed. The Williams \& Wilkins Co., Baltimore.

20. Márialigeti, K. 1979. On the community structure of the gut-microbiota of Eisenia lucens (Annelida, Oligochaeta). Pedobiologia 19:213-220.

21. Shirling, E. B., and D. Gottlieb. 1966. Methods for characterization of Strepomyces species. Int. J. Syst. Bacteriol. 16:313-340.

22. Skerman, V. B. D., V. McGowan, and P. H. A. Sneath (ed.). 1980. Approved lists of bacterial names. Int. J. Syst. Bacteriol. 30:225-420.

23. Tresner, H. D., and E. J. Backus. 1963. System of color wheels for streptomycete taxonomy. Appl. Microbiol. 11:335-338.

24. Yamaguchi, T. 1965. Comparison of the cell-wall composition of morphologically distinct actiomycetes. J. Bacteriol. 89:444-453. 